\title{
DESIGN AND FABRICATION OF AN EXTRACTION MACHINE FOR TOMATO SEEDS

\author{
M.E. El-Iraqi ${ }^{1}$; S.E. El Khawaga ${ }^{1}$ and T.R. Awais ${ }^{1}$
}

\begin{abstract}
\end{abstract}
An extraction machine for tomato seeds was designed, locally fabricated and evaluated. The performance of the designed extraction machine was evaluated based on seed loss, extraction efficiency, cleaning efficiency and energy requirements. The evaluation was calculated at different operation conditions including different crushing/separation speeds from 1.31 to $3.66 \mathrm{~m} / \mathrm{s}$, feed rates from 60 to $240 \mathrm{~kg} / \mathrm{h}$ and inclination angle of extraction unit from 0 to 12 deg. The obtained results concluded that:

- Increasing or decreasing the crushing/separating drum speed more or less than $2.88 \mathrm{~m} / \mathrm{s}$ and increasing or decreasing the inclination angle of extraction machine more or less than 8 deg were observed to cause an increase in seed losses, consequently caused a decrease in both of seed cleaning efficiency and seed extraction efficiency at any given feeding rates.

- The seed losses were found to be proportional to feeding rate. However, the seed cleaning efficiency, seed extracting efficiency and required energy were found to be inversely proportional to the feeding rate.

- Using the study variable combinations of $2.88 \mathrm{~m} / \mathrm{s}$ crushing/separating drum speed and 8 deg inclination angle gave the maximum values of seed extraction efficiency 95.20, 93.46, 92.60 and $90.73 \%$ at feeding rates of $60,120,180$ and $240 \mathrm{~kg} / \mathrm{h}$, respectively.

- Increasing the crushing/separating drum speed from 1.31 to $3.66 \mathrm{~m} / \mathrm{s}$ decreased the required energy from 11.04 to $16.90 \mathrm{~kW} . \mathrm{h} / \mathrm{ton}$ at a feed rate of $60 \mathrm{~kg} / \mathrm{h}$ and inclination angle of $8 \mathrm{deg}$. Utilizing the designed tomato seed extraction machine proved to be very cost effective and was able to save more than $37 \%$ in extraction cost.

\section{INTRODUCTION}

7 Tomato is one of the most popular vegetables, used as a salad, in food preparations and as juice, soup, puree, ketchup or paste.

L Tomato seeds, the major component of tomato pomace, contain a good quantity of proteins and lipids (Sogi and Bawa, 1998). The skin,

${ }^{1}$ Senior Researcher, Agric. Eng. Res. Inst., Agric. Res. Center, Egypt 
another important component of tomato pomace, is utilized for extracting the red pigment using organic solvents (Tonucci et al., 1995). Tomato (Lycopersiocon esculenthum Mill), comes as one of the most important agricultural products among fresh vegetables in Egypt. It is grown over an area of 0.559 million feddan and has a record annual production of 10.279 million tons (EAS, 2010).

Seed extraction techniques, often used, are natural fermentation, alkali treatments, acid treatments and mechanical means. Each technique has advantages and disadvantages depending on application period, concentration and temperature. The advantages of acid treatments are efficient breakdown of the gelatinous coating and quick cleaning, eradication of bacterial canker and inactivation of tomato mosaic virus (George, 1985). Similar cautions concerning excessive digestion time on seed quality and concern about worker safety when using concentrated acids need to be emphasized with this technique. Excessive fermentation reduces seed quality. However, it darkens the seed coats and makes the seeds less attractive as a commercial product (Stevens and Rik, 1986).

Efforts have been made by several researchers to design, develop and study the factors affecting the performance evaluation of seed extractors such as Vergano et al. (1992), who, stated that the performance data of the axial-flow vegetable seed extracting machine on different vegetable fruits and data on manual seed extraction showed that feed rate vegetable fruits with seed extracting machine varied from 310 to $1930 \mathrm{~kg} / \mathrm{h}$ for different vegetables. The seed extraction rate varied from 0.47 to 3.14 $\mathrm{kg} / \mathrm{man}-\mathrm{h}$ for different types of vegetable fruits. The seed extraction output was $0.47,1.20,1.26,1.56,1.83,2.20$ and $3.14 \mathrm{~kg} / \mathrm{man}-\mathrm{h}$ for cucumber, watermelon, tomato, summer squash, brinjal, squash melon and chillies, respectively. The seed loss for all vegetables except squash melon was below $5.86 \%$. The seed germination was over $79 \%$ in all cases except tomato and summer squash. The germination count for mechanically extracted seeds was higher than for the manually extracted seeds. In the same year, Kachru and Sherief (1992) evaluated and tested the performance of an axial flow vegetable seed extractor under five wet vegetables and fruits (tomato, brinjal, watermelon, muskmelon and 
pumpkin). The seed loss ranged between 0.82 and $15.02 \%$, and mechanical damage ranged between 0.97 and $5.79 \%$. The seed germination for tomato was $93 \%$.

However, Demir and Samit (2001) indicated that the two main factors that affect seed quality in tomato are seed harvest time and seed extraction method. Seed development studies in tomato showed that the maximum seed quality and the most resistant to acid extraction and natural fermentation treatments are obtained from fruits harvested when they are red-firm which occurs around 70 days after anthesis. Seed quality declined in earlier and later harvests. Kailappan et al. (2005) fabricated and evaluated a tomato seed extractor having a capacity of 180 $\mathrm{kg}$ of fruits per hour. The results indicated that the unit had a seed extraction efficiency of $98.8 \%$. As compared to manual method of seed extraction, the unit recorded $96.6 \%$ saving in time and $89.6 \%$ saving in cost. The cost of the unit was only about $\$ 190$. One year later, Thirupathi et al. (2006) developed and tested a unit for pulping and straining tomato fruits for its performance. Local and hybrid varieties were used for testing. Cold and hot pulping were carried out at different peripheral speeds. The maximum pulp extraction efficiency for the local variety was $91.0 \%$ by hot pulping at a peripheral speed of $47.1 \mathrm{~m} / \mathrm{s}$. The maximum pulp extraction efficiency for the hybrid variety was $92.3 \%$ by hot pulping at a peripheral speed of $47.1 \mathrm{~m} / \mathrm{s}$. The capacity of the unit was $110 \mathrm{~kg} / \mathrm{h}$. Also, Aviara et al. (2008) concluded that the performance evaluation of a guna seed extractor showed that the fruit moisture content, material feed rate and machine speed had a significant effect on its performance indices.

Moreover, Al-Gaadi et al. (2011) designed, manufactured and evaluated low-cost summer squash seed extraction machine. The evaluation was calculated at different operation conditions including different crushing drum speeds (ranging from 5.23 to $9.16 \mathrm{~m} / \mathrm{s}$ ), feed rates (ranging from 300 to $1200 \mathrm{~kg} / \mathrm{h}$ ) and wet-based (wb) vegetable moisture contents, MC (ranging from 82.03 to $93.54 \%$ ). Results revealed that the seed loss was proportional to the feed rate and inversely proportional to the MC. At all other variable levels, the minimum loss was found at drum speed of 6.54 
$\mathrm{m} / \mathrm{s}$. The broken seeds, however, were found to decrease with increasing feed rate and MC and increase with increasing drum speed. For the extraction efficiency, it was found to be proportional to the $\mathrm{MC}$ and inversely proportional to the feed rate approaching its maximum value at a $6.54 \mathrm{~m} / \mathrm{s}$ drum speed with all other variable levels. Increasing the feed rate from 300 .to $1200 \mathrm{~kg} / \mathrm{h}$ decreased the required energy from 83 to 38 $\mathrm{kW} . \mathrm{h} / \mathrm{t}$. Operation cost analysis showed that the extraction cost by the machine was at $20.23 \$$ /ton compared to $192 \$$ /ton for manual seed extraction. Hence, a saving of above $89 \%$ can be achieved using the developed machine.

\section{Problem statement}

The extraction of seed from tomato fruits is presently carried out by manual method and is still the dominant extraction procedure in Egypt. This method of seed production is highly labor intensive, costly, low productive, slow and time consuming process. Also, it is considered one of the important reasons for the lack of quality seed production available in Egypt. Mechanization of seed extraction can play, or at least, greatly decrease the drawbacks associated with manual extraction. Moreover, imported seed extraction machines are expensive and inefficient as they were not designed to suit most Egyptian vegetables and seed properties.

Therefore, the main objective of this study was to design, and locally fabricate a tomato seed extraction machine to extract tomato seeds beside collecting the flesh portions of tomato for production of tomato pulp and paste, as one of the necessary post harvest operations for minimizing the losses of tomato fruits during harvest period which is considered a severe problem facing all producers of tomato crop, especially in the newly reclaimed lands during times of overproduction. However, the specific objectives include the evaluation of the mechanical extraction performance and cost analysis of the mechanical extraction comparing with manual extraction method.

\section{MATERIALS AND METHODS}

In this research, an extraction machine for tomato seeds was designed, locally fabricated and evaluated. Seed extraction by the machine was conducted by first crushing the tomato fruits, then separating the seeds from flesh, juice and other fruit materials. The designed prototype of 
extraction machine was fabricated at some private workshop in Damanhur city, Egypt, in 2009. While the evaluation experiments of extraction machine were carried out at Rice Mechanization Center, Agric. Eng. Res. Institute, Kafr El-Sheikh governorate using tomato fruits of Peto-86 Variety in 2009 and 2010 seasons.

\section{1-Construction of the extraction machine}

The machine technical specifications are summarized in Table (1), while the main components of the designed extraction machine for tomato seeds are illustrated Fig. (1):-

Table (1): The technical specification of the designed extraction machine.

\begin{tabular}{|c|c|c|}
\hline \multicolumn{2}{|c|}{ Items } & Specifications \\
\hline \multirow{3}{*}{$\begin{array}{l}\text { Overall } \\
\text { dimensions, } \mathbf{m m}\end{array}$} & Length & 1800 \\
\hline & Width & 800 \\
\hline & Height & 1400 \\
\hline \multicolumn{2}{|l|}{ Mass, kg } & 167 \\
\hline \multirow{2}{*}{$\begin{array}{l}\text { Crushing unit } \\
\text { dimensions, mm }\end{array}$} & Diameter & 75 \\
\hline & Length & 250 \\
\hline \multirow{5}{*}{$\begin{array}{l}\text { Separating unit } \\
\text { dimensions, mm }\end{array}$} & Diameter & 800 \\
\hline & Length & 800 \\
\hline & No. of beaters & 3 \\
\hline & Beater length & 750 \\
\hline & Beater width & 50 \\
\hline \multirow[t]{2}{*}{ Power unit } & Type & Three phase electric motor \\
\hline & Power, kW (hp) & $0.75(1)$ \\
\hline
\end{tabular}

\section{1- Main frame and feed hopper}

The main frame was constructed from rectangular mild steel tube $50 \times 50$ and $60 \times 60 \mathrm{~mm}$. The main frame was mounted on four stands, two of them were flexible to facilitate flow of tomato juice after extracting by adjusting the inclination angle of extracting machine on the ground horizontal level. The feed hopper was made of steel sheet of $1 \mathrm{~mm}$ thickness and fixed on the main frame to move tomato fruits into the crushing/squeezing unit by gravity. Its capacity was about $25-30 \mathrm{~kg}$ of tomato fruits. 


\section{2- Crushing unit}

The crushing unit consists of screw auger and cylindrical case. The stainless steel screw auger was made of $3 \mathrm{~mm}$ thick mild steel round sheet. The diameter and pitch of the screw auger were 65 and $135 \mathrm{~mm}$, respectively. Meanwhile, the auger case was fabricated from stainless steel cylindrical tube with inner diameter of 75 and length of $280 \mathrm{~mm}$. The screw auger of crushing unit was fixed on the rotor shaft which was supported with $25 \mathrm{~mm}$ two ball bearings on its two ends.

In the crushing, unit the tomato fruits which coming from feeding hopper, are crushed and squeezed by the rotating screw auger and internal corrugations of the auger case then go out to the separation unit.

\section{3- Separation unit}

The separation unit consists of cylindrical drum, upper drum cover, bottom drum concave/strainer and discharge outlets of tomato flesh, seeds and juice. The cylindrical separation drum is equipped with three beaters $(800 \mathrm{~mm}$ length and $50 \mathrm{~mm}$ width) fixed on the rotor shaft of crushing unit. The clearance between beater and concave can be adjusted. The bottom drum concave consists of inner strainer and outer concave. The strainer is made from perforated stainless steel sheet with $2 \mathrm{~mm}$ thickness, $3.5 \mathrm{~mm}$ diameter of mesh and No. of mesh is $4 / \mathrm{cm}^{2}$. The discharge outlets were provided at the bottom and lower end of inner and outer concaves to collect the tomato flesh, seeds and juice.

The main function of separation unit is to separate the tomato seeds from its flesh and skin through the outlet of lower concave and collect them in a container placed down the extracting machine while the flesh and skin go through the outlet of the separation unit.

\section{4- Power unit and power transmission}

An electrical motor of three phase and $1 \mathrm{hp}(0.75 \mathrm{~kW})$ was used as the power source to drive the crushing and separation units. This motor was equipped with low rpm transmission gearbox (a worm gear and pinion) and four different diameter pulleys and belts arrangement to transfer power from the motor to the extraction unit and to vary the crushing/separating drum speed. The group pulley diameters at the motor shaft were 150,115, 100 and $90 \mathrm{~mm}$, while the group pulleys at the crushing/separating drum shaft were $90,110,130$ and $150 \mathrm{~mm}$ and 
V-belts to get the desirable crushing/separating drum speeds of 50,80 , 100 and $140 \mathrm{rpm}(1.31,2.09,2.88$ and $3.66 \mathrm{~m} / \mathrm{s}$, respectively).

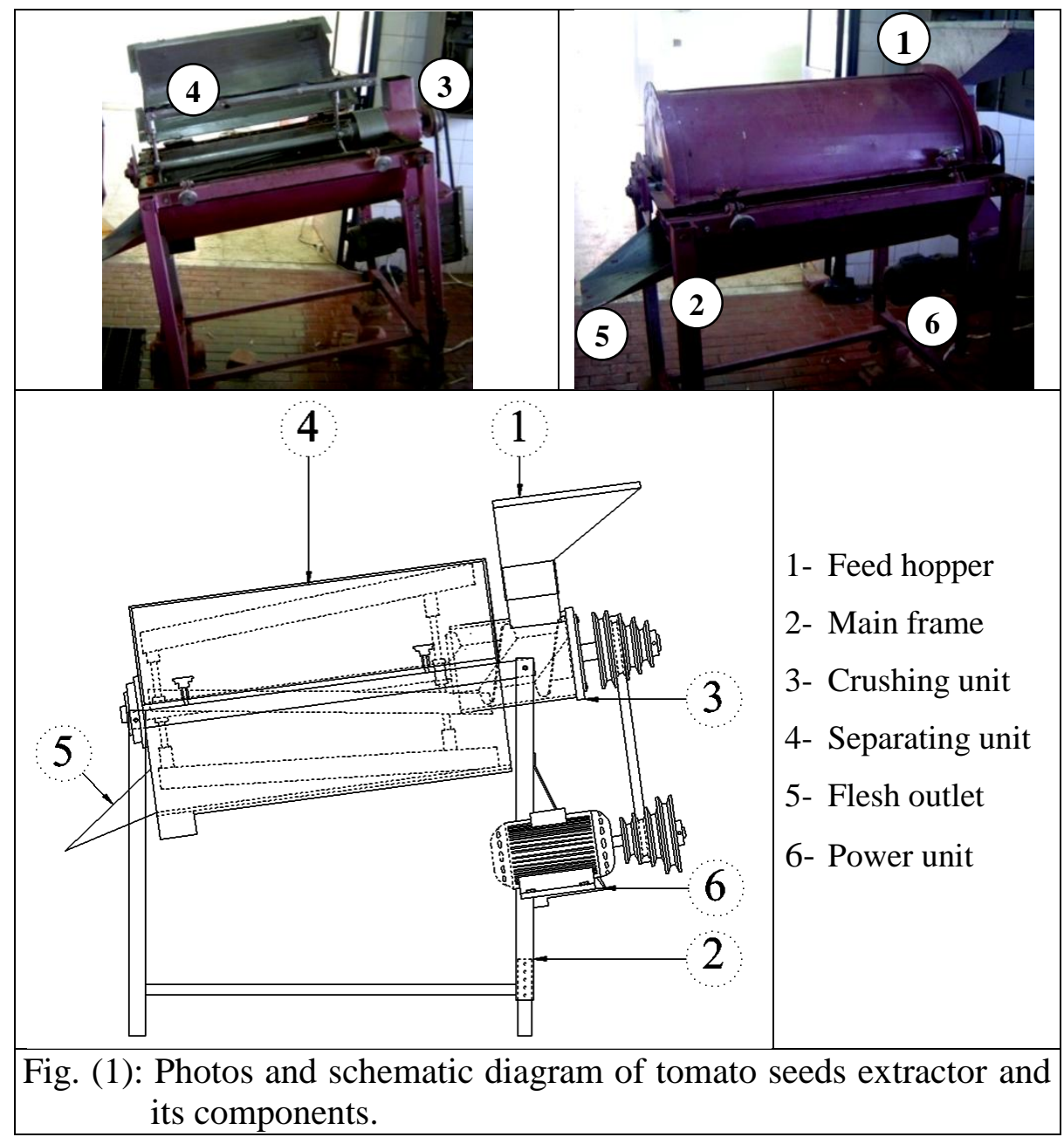

\section{2-Study variables}

The designed extracting machine was tested and evaluated in this study under the following variables:

1- Four different crushing/separating drum speeds 1.31, 2.09, 2.88 and $3.66 \mathrm{~m} / \mathrm{s}(50,80,100$ and $140 \mathrm{rpm}$, respectively).

2- Four different of feeding rates, 60, 120, 180 and $240 \mathrm{~kg} / \mathrm{h}$ of Peto-86 tomato variety fruits. 
3- Four different inclination angles of the extraction machine on the ground horizontal level: $0,4,8$ and 12 degrees.

\section{3-Measurements}

To achieve the main objective of this study, the following measurements were taken into consideration during testing and evaluation of the designed tomato seeds extracting machine;

\section{3-1-Physical and mechanical properties}

Some physical and mechanical properties of tomato fruits and seeds were determined to generate some essential engineering data for designing tomato seed extractor. A number of 50 fruits were randomly chosen to determine the physical properties such as fruit size, mass, volume and density, in addition to fruit moisture content and fruits seed-pulp contents $\%$. Meanwhile, the crushing strength was determined as a mechanical property of the tomato fruits. Measurements of physical and mechanical properties were done in laboratory of Rice Mechanization Center, Agric Eng. Res. Institute using Peto-86 tomato variety fruits and the obtained results are summarized in Table (2).

Table (2): Average data of physical and mechanical properties of Peto-86 tomato fruit variety.

\begin{tabular}{|c|c|c|c|c|c|}
\hline \multicolumn{3}{|c|}{ Measurement } & Av. & SD & $\mathrm{CV}, \%$ \\
\hline \multirow{10}{*}{$\begin{array}{c}\text { Physical } \\
\text { properties }\end{array}$} & \multirow{2}{*}{$\begin{array}{l}\text { 1- Fruit } \\
\text { dimensions, } \mathrm{mm}\end{array}$} & Major diameter & 56.20 & 5.78 & 10.28 \\
\hline & & Minor diameter & 52.04 & 5.11 & 9.93 \\
\hline & \multicolumn{2}{|l|}{ 2- Mass, g } & 96.15 & 22.42 & 23.25 \\
\hline & \multicolumn{2}{|l|}{ 3- Volume, $\mathrm{cm}^{3}$} & 119.94 & 31.54 & 26.30 \\
\hline & \multicolumn{2}{|c|}{ 4- Fruit density, $\mathrm{g} / \mathrm{cm}^{3}$} & 0.95 & 0.08 & 8.17 \\
\hline & \multirow{2}{*}{$\begin{array}{l}\text { 3-Moisture } \\
\text { content, \% (wb) }\end{array}$} & Pulp & 59.29 & & \\
\hline & & seed & 91.78 & & \\
\hline & \multirow{3}{*}{$\begin{array}{l}\text { 5- Contents per } \\
\text { fruit, } \%\end{array}$} & Flesh $(\mathrm{P}$ & 62.67 & 0.80 & 0.32 \\
\hline & & seeds & 7.21 & 0.15 & 0.52 \\
\hline & & juice & 30.11 & 0.85 & 0.71 \\
\hline \multirow{2}{*}{$\begin{array}{c}\text { Mechanical } \\
\text { properties }\end{array}$} & \multirow{2}{*}{$\begin{array}{l}\text { Crushing strength } \\
\mathbf{N}\end{array}$} & $\begin{array}{l}\text { Along } \\
\text { longitudinal axis }\end{array}$ & 38.72 & 1.01 & 1.05 \\
\hline & & Along cross axis & 47.43 & 1.53 & 1.10 \\
\hline
\end{tabular}


The size of the fruit was determined using a digital vernier caliper with a least count of $0.001 \mathrm{~mm}$. The diameters were measured along the longitudinal and cross-sectional axis as shown in Fig (2-a). The mass of the tomato fruits was determined by using a digital scale with an accuracy of 0.01g (as used by Mohsenin 1980) as shown in Fig (2-b). The individual masses of seed, pulp (juice) and skin present in the tomato fruits were determined by separating them manually. The moisture contents $(\mathrm{wb})$ of the seed, pulp and the skin were determined by keeping samples in a controlled electric oven at $130 \pm 1 \mathrm{c}^{\circ}$ for one hour (AOAC 1967).

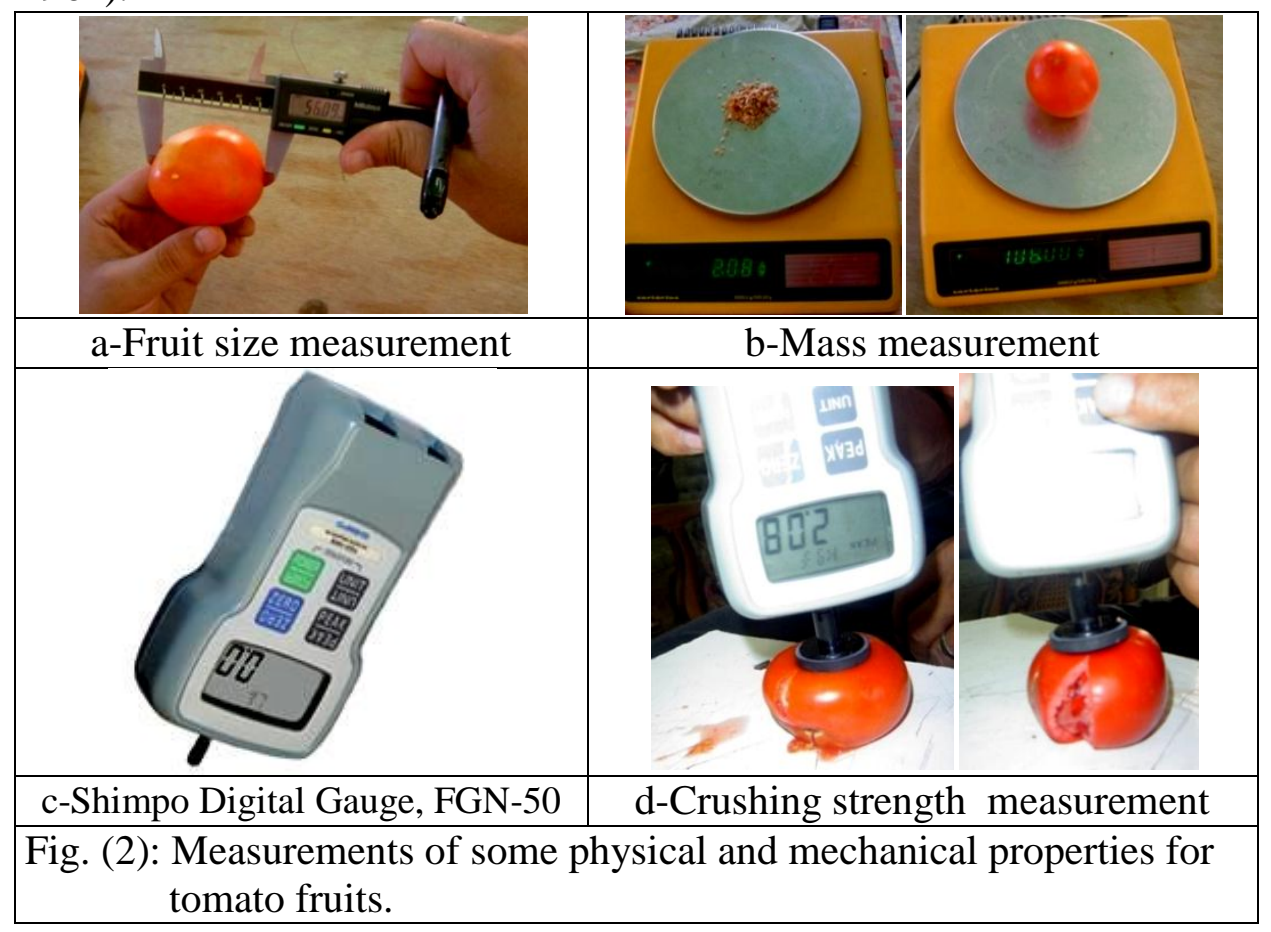

The crushing strength is the force required to crush the tomato fruit to take out the seed and pulp from the fruits. The crushing strength was determined for tomato fruits by using a Shimpo Digital Gauge, FGN-50 (Japanese made). Incremental load was applied to the fruit till the tomato fruit is crushed as shown in Fig (2-c and d). The recorded reading of crushing strength in $\mathrm{N}$ on the instrument screen was taken. The crushing strength for tomato fruits was determined by selecting 10 fruits in random and the mean values are reported with standard deviation. Measurements were carried out in the longitudinal and cross directions. 


\section{3-2- Seed cleaning efficiency}

Three samples of output tomato seeds (about 250g for each) were taken from seeds receiving container for each treatment under the different study variables. The samples of seeds were weighed and the pieces of flesh, pulp and skin sticking on the seeds were manually separated and weighed. The cleaning efficiency was calculated according the following equation:

Cleaning efficiency, $\%=1-\frac{M_{\text {flesh }}}{M_{\text {sample }}} \times 100$

Where: $M_{\text {flesh }}=$ Mass of flesh and skin mixed with the tomato seed sample, g, and

$M_{\text {sample }}=$ Mass of seed sample, $\mathrm{g}$.

\section{3-3-Seed losses and extraction efficiency}

The seed losses were determined by recovering the seeds mixed with other tomato material collected from the separation outlets, during each test, by dipping into water and separation by gentle agitation. The percentages of seed losses were determined for each treatment at the different study variables using the following equation:

Seed losses, $\%=\frac{M_{1}}{M_{1}+M_{2}} \times 100$

However, the seed extraction efficiency (\%) was determined from the following equation:

Seed extraction efficiency, $\%=\frac{M_{2}}{M_{1}+M_{2}} \times 100$

Where:

$M_{1}=$ Mass of collected seeds mixed with other tomato material at separation outlets, $\mathrm{g}$,

$M_{2}=$ Mass of clean seeds collected from seed outlet, $\mathrm{g}$.

\section{3-4- Germination ratio}

The germination tests were run in $9.0 \mathrm{~cm}$ diameter Petri dishes containing a disc filter paper moistened with distilled water. Seeds of tomato were placed, equally spaced (50 seeds per dish), three replications of each treatment. The Petri dishes were enclosed and kept in an 
incubator at $25^{\circ} \mathrm{C}$ in the darkness for 10 days. The number of germinated seeds in each dish were counted daily 3 days after the start experiment, up to the $10^{\text {th }}$ day (AOSA, 2000). The germination ratio was calculated using the following formula:

Germination ratio, $\%=\frac{\text { No. of germinated seeds }}{\text { Total No. of tested seeds }} \times 100$

\section{3-5-Power consumption and energy requirements}

The consumed power $(k W)$ and the energy requirements $(k W . h / t o n)$ were calculated by measuring the phase current strength (I) and voltage (V) of the used electrical three phase motor under study according to the following equations (Ibrahim, 1982 and Awady, 2011):

Power consumption $(k W)=\frac{\sqrt{3} I V \eta \operatorname{Cos} \theta}{1000}$

Energy requirement $(k W . h /$ ton $)=\frac{\text { Power consumption }(k W)}{\text { Productivity }(\text { ton } / h)}$

Where:

$I=$ Phase current strength (Ampere)

$V=$ Phase voltage (Volt)

$\eta=$ Mechanical efficiency (taken about 90\%)

$\operatorname{Cos} \theta=$ power factor (taken about 0.84 )

\section{3-6- Cost analysis}

The manual and mechanical extraction costs were analyzed to clear the economic objective of this study. The manual extraction cost was determined as average of required laborers to perform seed extraction of one Feddan of tomato fruits, within one working day, assuming the tomato productivity of about 30 ton/fed, 90 laborers/fed and 30 LE/day, based on field experience reported by local farmers.

The total manual extraction $\operatorname{cost}(L E / h)=\frac{\text { No. of labors } \times \text { Labor } \cos t(L E / \text { day })}{8}$

The total manual extraction cost $($ LE/ton $)=\frac{\text { Total manual extraction } \operatorname{cost}(L E / h)}{\text { total labor productivity }(\text { ton } / h)}$

However, the extraction cost, using the designed extraction machine, included the fixed, operation and total costs, LE/h or LE/ton were calculated as follows: 
The machine fixed costs included depreciation, interest, taxes, housing and insurance. The annual capital consumption, which included the depreciation and the interest costs, was estimated at $25 \%$ of the machine cost ,(Hunt, 1983). However the remaining elements of fixed costs (taxes and housing) were annually assumed to be $2 \%$ of the machine cost, (Hunt, 1983). With assumption of machine life expectancy 5 years, 300 operating hours per year and the extraction machine cost of $5000 \mathrm{LE}$ could determine the machine fixed cost (LE/h).

The machine operation costs included the cost of labor, electric power consumption, repair and maintenance. The labor cost was calculated based on the fact that two laborers were required to properly operate the machine and $30 \mathrm{LE} /$ day for each labor ( 8 hours/day). The electric power cost of the machine was determined to be $0.2 \mathrm{LE} / \mathrm{kW}$ at the study variable levels of 0 deg inclination angle, $240 \mathrm{~kg} / \mathrm{h}$ feed rate and $3.66 \mathrm{~m} / \mathrm{s}$ drum speed. However, the cost of repair and maintenance was estimated at $2 \%$ of the machine cost per 100 hours of operation, (Hunt, 1983).

The total mechanical extraction $\operatorname{cost}(L E / h)=$ Fixed $\operatorname{cost}(L E / h)+$ Operation $\operatorname{cost}(L E / h)$

$$
\text { The total mechanical extraction } \operatorname{cost}(\text { LE/ton })=\frac{\text { Total } \operatorname{cost}(\text { LE/h })}{\text { Machine productivity }(\text { ton } / h)}
$$

\section{RESULTS AND DISCUSSION}

\section{1- Seed cleaning efficiency}

The relation between the crushing/separating drum speed, inclination angle of extraction machine on the ground horizontal level, feeding rate of peto-86 tomato variety fruits and the seed cleaning efficiency are illustrated in Fig. (3). As shown in this figure, it could be indicated that, the seed cleaning efficiency $(\%)$ increased by increasing the crushing/separating speed up to $2.88 \mathrm{~m} / \mathrm{s}$ and inclination angle up to 8 deg at any given feeding rate. However, by increasing crushing speed than $2.88 \mathrm{~m} / \mathrm{s}$, and increasing, inclination angle than $8 \mathrm{deg}$, result in a decrement percentage in seed cleaning efficiency. These results may be due to increasing the centrifugal force of separation unit by increasing crushing/separating speed up to $2.88 \mathrm{~m} / \mathrm{s}$ and inclination angle up to 8 deg, which gave enough separation time for small parts of flesh and pulp 
to discharge from seed outlet, resulting in a good separation and seed cleaning efficiency. Meanwhile, by increasing the crushing/separating speed than $2.88 \mathrm{~m} / \mathrm{s}$ and inclination angle than 8 deg decrease the chance of flesh/pulp separation time, which gave a low value of seed cleaning efficiency.

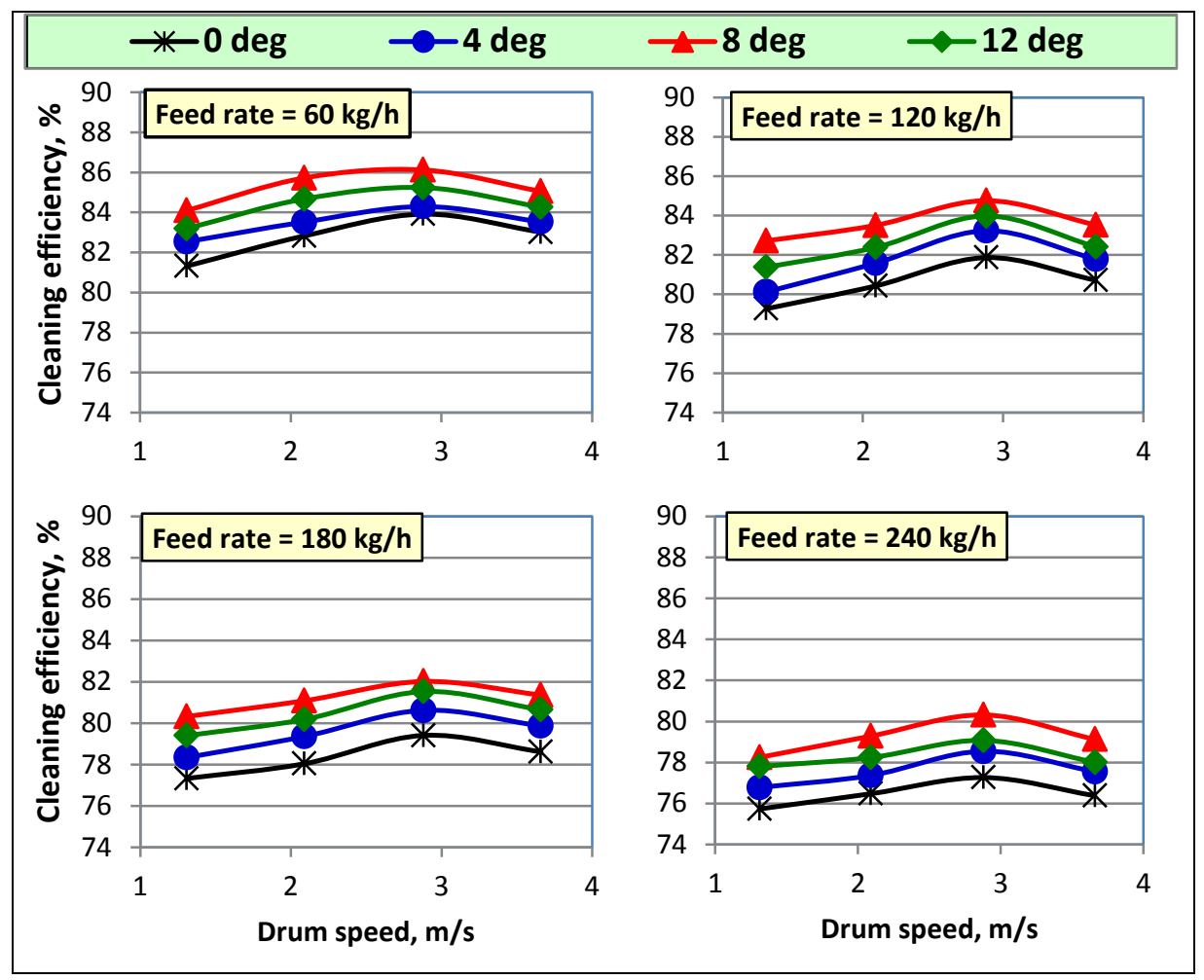

Fig (3): Effect of studied operation variables on the seed cleaning efficiency.

Using the study variable combinations of $2.88 \mathrm{~m} / \mathrm{s}$ crushing/separating drum speed and inclination angle of $8 \mathrm{deg}$ gave the highest values of seed cleaning efficiency of $86.12,84.76,82.02$ and $80.32 \%$ at feeding rate of 60, 120, 180 and $240 \mathrm{~kg} / \mathrm{h}$, respectively. However, by using study variable combinations of $1.31 \mathrm{~m} / \mathrm{s}$ crushing/separating speed and inclination angle of $0 \mathrm{deg}$ gave the lowest values of seed cleaning efficiency, 81.32, 79.27, 77.33 and $75.73 \%$ at feeding rate of 60,120 , 180 and $240 \mathrm{~kg} / \mathrm{h}$, respectively . 
Also, it could be observed that, the seed cleaning efficiency decreased by increasing feeding rate at other given study variable levels. An increase in feeding rate from 60 to $240 \mathrm{~kg} / \mathrm{h}$ caused a drop in the percentage of seed cleaning efficiency from 86.12 to $80.32 \%$ at crushing/separating speed of $2.88 \mathrm{~m} / \mathrm{s}$ and inclination angle of $8 \mathrm{deg}$. These results may be due to more small fruit pulp parts discharged to the seed discharge outlet as the feeding rate increased.

\section{2- Seed losses}

The obtained results of seed losses affected by the different operation variables under study, are shown in Fig. (4). From this figure it could be concluded that the seed losses increased with any increase in crushing/separating speed up to $2.88 \mathrm{~m} / \mathrm{s}$ and inclination angle up to 8 deg at any given feeding rate under study. However, with any increase in crushing/separating speed more than $2.88 \mathrm{~m} / \mathrm{s}$ and inclination angle more than $8 \mathrm{deg}$, the seed losses decreased at any given feeding rate of tomatoes fruits. The decrease in seed losses as the crushing/separating drum speed increased from $1.33 \mathrm{~m} / \mathrm{s}$ to $2.88 \mathrm{~m} / \mathrm{s}$ and increasing the inclination angle levels from 0 to $8 \mathrm{deg}$ were attributed to the seed losses that increased with the rate of pulping to a certain limit, and then fruits were conveyed without pulping as the contact time between separation drum, and its concave and the fruits decreased. Hence, higher seed losses prevailed. A crushing/separating drum speed beyond $2.88 \mathrm{~m} / \mathrm{s}$ and an inclination angle more $8 \mathrm{deg}$ provided less time for the seeds to pass through the concave holes, leading to increase seed losses. A maximum seed losses of $14.31 \%$ occurred at crushing/separating drum speed of $1.33 \mathrm{~m} / \mathrm{s}$, inclination angle of $0 \mathrm{deg}$ and feeding rate of $240 \mathrm{~kg} / \mathrm{h}$. However, the minimum seed losses of $4.80 \%$ were achieved at crushing/separating drum speed of $2.88 \mathrm{~m} / \mathrm{s}$, inclination angle of $8 \mathrm{deg}$ and feeding rate of $60 \mathrm{~kg} / \mathrm{h}$.

It can also be seen from Fig. (4) that the tomato seed losses during extraction process increased with an increase in feeding rate at any other given study variable levels. At a crushing/separating drum speed of 2.88 $\mathrm{m} / \mathrm{s}$ and an inclination angle of $8 \mathrm{deg}$ it was observed that the percentage 
of seed losses increased from 4.80 to $9.27 \%$ as the feeding rate increased from 60 to $240 \mathrm{~kg} / \mathrm{h}$. These results may be attributed to more tomato fruits discharged to the clearance between the crushing drum and the concave causing less crushing effect and higher seed loss during separation process.

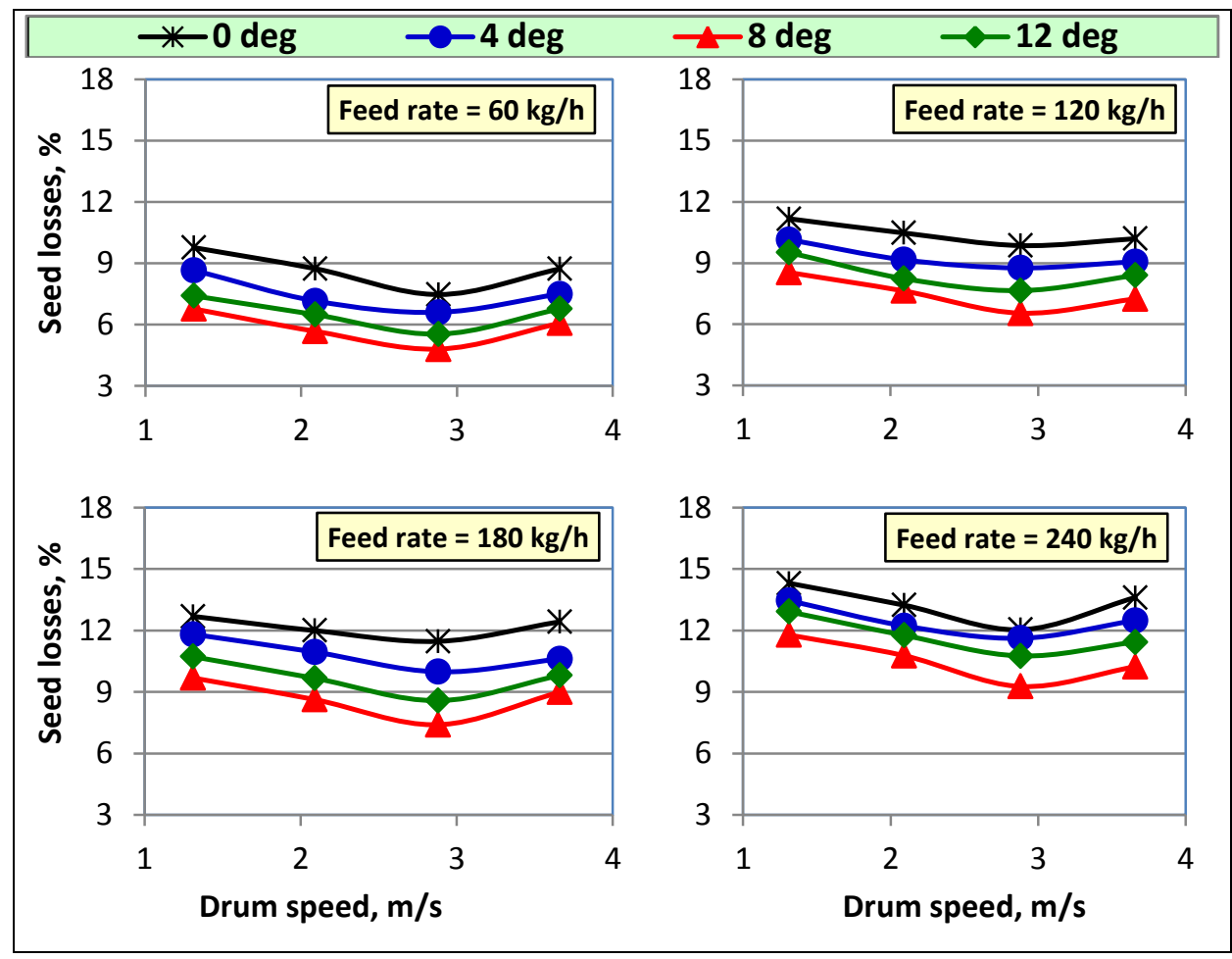

Fig (4): Effect of studied operation variables on the seed losses.

\section{3- Seed extracting efficiency}

The effect of crushing/separating speed and inclination angle of extraction unit on the seed extraction efficiency at different feeding rates of peto-86 tomato variety fruits are demonstrated in Fig. (5). The general trend presented in this figure, shows that the crushing/separating drum speed and inclination angle were effective factors on the seed extraction efficiency. Increasing or decreasing the crushing/separating drum speed more or less than $2.88 \mathrm{~m} / \mathrm{s}$ and increasing or decreasing the inclination angle of extraction machine more or less than $8 \mathrm{deg}$ were observed to 
cause a decrease in seed extraction efficiency. These results may be due to the fact that the seed losses were found to be increased with an increase or decrease in the crushing/separating drum speed more or less than $2.88 \mathrm{~m} / \mathrm{s}$ and in the inclination angle of extraction machine more or less than $8 \mathrm{deg}$, hence, lower extraction efficiency.

At feeding rate of $60 \mathrm{~kg} / \mathrm{h}$ and inclination angle of $8 \mathrm{deg}$, the seed extraction efficiency increased from 93.23 to $95.20 \%$ as the crushing/separating drum speed increased from 1.33 to $2.88 \mathrm{~m} / \mathrm{s}$ and decreased from 95.20 to $93.93 \%$ as the crushing/separating speed increased from 2.88 to $3.66 \mathrm{~m} / \mathrm{s}$. In the other side, at feeding rate of 60 $\mathrm{kg} / \mathrm{h}$ and crushing/separating drum speed of $2.88 \mathrm{~m} / \mathrm{s}$, the seed extraction efficiency increased from 92.53 to $95.20 \%$ as the inclination angle increased from 0 deg to 8 deg and decreased from 95.20 to $94.46 \%$ as the inclination angle increased from $8 \mathrm{deg}$ to $12 \mathrm{deg}$.

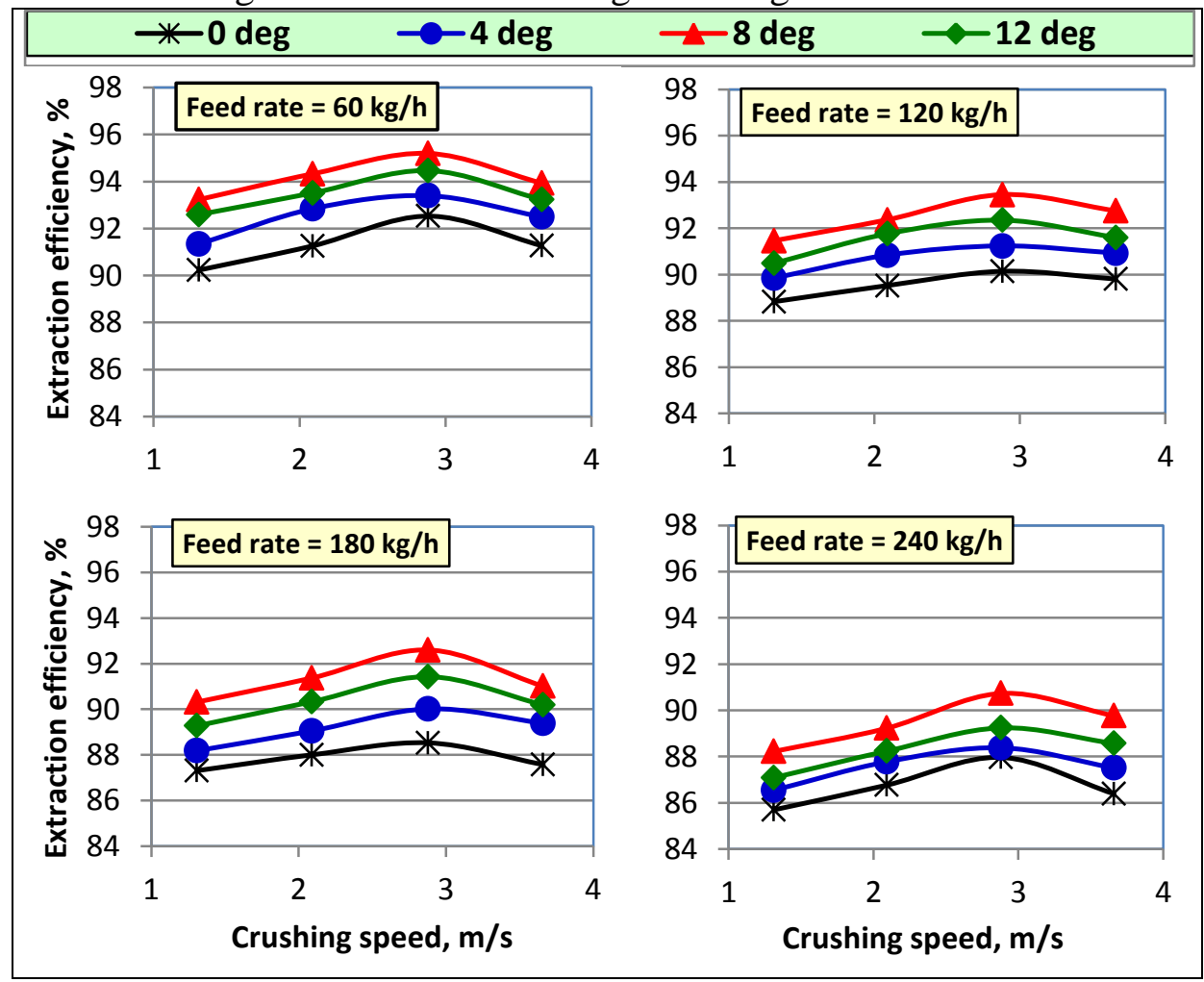

Fig (5): Effect of study operation variables on the seed extracting efficiency. 
Also, the data shown in Fig. (5) indicate that an increase in feeding rate of tomato fruits results in a decrement percentage in seed extraction efficiency under any other given study variable levels. Using the designed extraction machine under the study variable combinations of $2.88 \mathrm{~m} / \mathrm{s}$ crushing/separating speed and inclination angle of $8 \mathrm{deg}$ gave the maximum values of seed extraction efficiencies 95.20, 93.46, 92.60 and $90.73 \%$ at feeding rates of $60,120,180$ and $240 \mathrm{~kg} / \mathrm{h}$, respectively. However, the minimum values of seed extraction efficiency $90.23,88.83$, 87.31 and $85.69 \%$ were obtained at feeding rates of 60, 120, 180 and $240 \mathrm{~kg} / \mathrm{h}$, respectively with the combination of $1.31 \mathrm{~m} / \mathrm{s}$ crushing/separating speed and $0 \mathrm{deg}$ inclination angle. This was attributed to the fact that the seed losses were found to increase with higher feeding rates.

\section{4- Germination ratio}

The obtained results of germination ratio indicated that using mechanical extraction for tomato seeds gave same results when using manual extraction seeds. The average values of germination ratio of mechanically extracted tomato seeds were ranged from 86-91\%. However, it were ranged from $86-92 \%$ for manually extracted tomato seeds. These results means that, there is no direct or indirect effect of using modified extraction machine for extracting tomato seeds.

\section{5- Energy requirements}

The average values of the energy requirements at different inclination degrees, as affected by feeding rate and crushing speed are illustrated in Fig. (5). The general trend shown in this figure clarifies that the required energy at a given feeding rate, was found to be proportional and inversely proportional to the crushing/separating speed and the inclination angle, respectively. As the drum speed increased from 1.31 to $3.66 \mathrm{~m} / \mathrm{s}$, the required energy rose from 11.04 to $16.90 \mathrm{~kW} . \mathrm{h} /$ ton at a feed rate of 60 $\mathrm{kg} / \mathrm{h}$ and inclination angle of $8 \mathrm{deg}$. However, it decreased from 14.88 to $13.94 \mathrm{~kW} . \mathrm{h} /$ ton as the inclination angle increased from 0 to 12 degrees at crushing/separating speed of $2.88 \mathrm{~m} / \mathrm{s}$ and feeding rate of $60 \mathrm{~kg} / \mathrm{h}$. 
It could be observed also that the required energy decreased with an increase in feeding rate at other studied variables. The required energy dropped from 16.90 to $6.68 \mathrm{~kW} . \mathrm{h} /$ ton as the feed rate increased from 60 to $240 \mathrm{~kg} / \mathrm{h}$ at a crushing/separating speed of $3.66 \mathrm{~m} / \mathrm{s}$ and inclination angle of $8 \mathrm{deg}$.

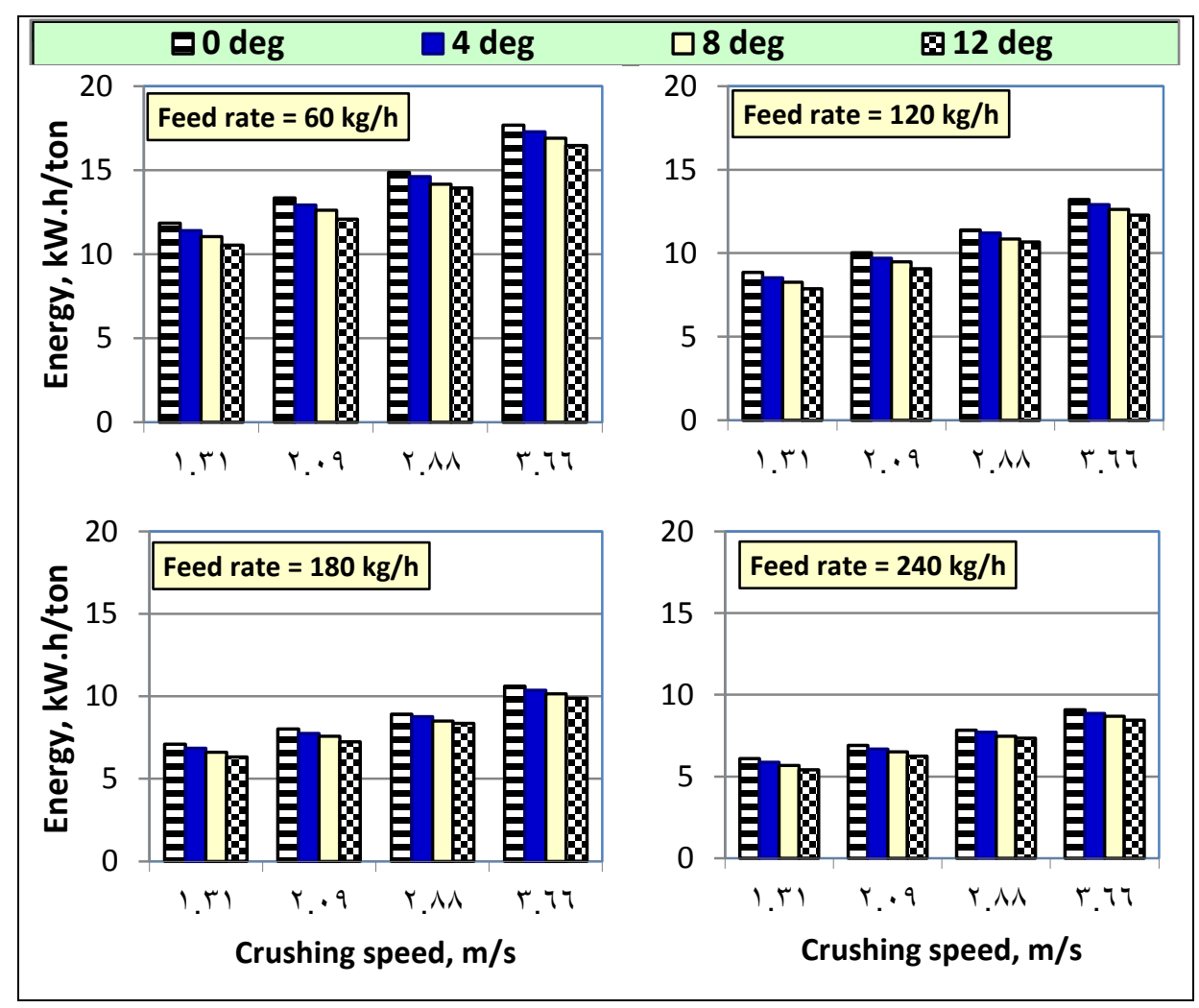

Fig (6): Effect of studied operation variables on the energy requirement.

\section{6- Cost analysis}

The cost analysis of tomato seed extraction process using the designed extraction machine concluded that the machine fixed cost, operation cost and the total mechanical extraction cost were 4.5 LE/h, 8.94 LE/h and 13.44 LE/h, respectively. The mechanical extraction cost was found to be increased from 55.98 LE/ton when using the designed extraction machine 
to $90.80 \mathrm{LE} /$ ton when manual extraction was implemented. Therefore, utilizing the designed tomato seed extraction machine was proven to be very cost effective and was able to save more than $37 \%$, in extraction cost.

\section{CONCLUSION}

- Increasing or decreasing the crushing/separating drum speed more or less than $2.88 \mathrm{~m} / \mathrm{s}$ and increasing or decreasing the inclination angle of extraction machine more or less than $8 \mathrm{deg}$ were observed to cause an increase in both of seed cleaning efficiency and seed losses, consequently caused a decrease in seed extraction efficiency at any given feeding rate.

- The seed losses were found to be proportional to feeding rate. However, the seed cleaning efficiency, seed extracting efficiency and required energy were found to be inversely proportional to the feeding rate.

- Using the study variable combinations of $2.88 \mathrm{~m} / \mathrm{s}$ crushing/separating speed and inclination angle of 8 deg gave the maximum values of seed extraction efficiency $95.20,93.46,92.60$ and $90.73 \%$ at feeding rate of $60,120,180$ and $240 \mathrm{~kg} / \mathrm{h}$, respectively.

- The required energy was found to be proportional to the crushing/separating speed and inversely proportional to the inclination angle. The required energy rose from 11.04 to $16.90 \mathrm{~kW} . \mathrm{h} / \mathrm{ton}$, as the drum speed increased from 1.31 to $3.66 \mathrm{~m} / \mathrm{s}$, at a feed rate of $60 \mathrm{~kg} / \mathrm{h}$ and inclination angle of $8 \mathrm{deg}$.

- Tomato seed extraction cost analysis showed that the extraction cost by the machine was $55.98 \mathrm{LE} /$ ton compared to $90.00 \mathrm{LE} /$ ton for manual seed extraction. Hence, a saving of above $37 \% \%$ can be achieved using the designed extraction machine. 


\section{REFERENCES}

Al-Gaadi K. A.; S. A. Marey and I. F. Sayed-Ahmed (2011). Development and performance evaluation of a summer squash seed extraction machine. Middle-East J. Sc. Res. 7 (3): 352-361. ISSN 1990-9233. IDOSI Pub.

AOAC (1976). Approved methods association of analytical chemists, 13th end. St. Paul, Minnesota : 234-238.

AOSA (2000). Association of Official Seed Analysts, Contrib. 29. Handbook on seed testing. Lincoln, NE: AOSA. 302p.

Aviara, N. A., S. K. Shittu and M. A. Haque, (2008). Development and performance evaluation of a guna seed extractor. Ag. Eng. I. : the CIGRE J., manuscript PM 07036, Vol. X, : 120-142.

Awady, M. N. (2011). Measuring instruments, TxtBk., Ag. Eng. Dept., Al Azhar U. and Ain Shams U., : 161p. (In Arabic).

Demir, I. and Y. Samit (2001). Quality of tomato seeds as affected by fruit maturity at harvest and seed extraction method. Gartenbauwissenschaft, 66 (4). S: 199-202, ISSN 0016-478X. Verlag Eugen Ulmer GmbH \& Co., Stuttgart, (Ankara/Turkey).

EAS (2010). Economic Affairs Sector, Egyptian Min. Ag. and Land Recl., Ag. statistics. Table No. (5-6).

George, R. A. T. (1985) : Vegetable seed production. Longman, London: 57-89.

Hunt, D. (1983). Farm power and machinery management. $8^{\text {th }}$ ed. Iowa state Univ. Press. Ames, Iowa, USA: 86-107.

Ibrahim, M. K. (1982). Wet milling of wheat grain, M.Sc. Th., Fac. of Agric., Mansoura Univ., Egypt.

Kachru, R. P. and J. T. Sheriff (1992). Performance evaluation of axial flow vegetable seed extractor. Indian J. of Ag. Eng., 2(1): 37-40. 
Kailappan R.; P. K. Baig; N. Varadharaju; K. Appavu; and V. Krishnasamy (2005). Fabrication and testing of tomato seed extractor. Agric Mech Asia Afr Lat Am, VOL.36; 62-66.

Mohsenin N. N. (1980). Physical properties of plant and animal materials: Godon And Breach Science Publishers, New York :183205.

Sogi, D. S., and A. S. Bawa (1998). Studies on dehydration of tomato processing waste. Indian Food Packer, 52(2),: 26-29.

Stevens, M. A. and C. M. Rick (1986). Genetics and breading in J. G. Atherton and J. Rudich (Eds) "The Tomato Crop"; P:35-109. Chapman and Hall, London.

Tonucci, L. H., J. M. Holden , G. R. Beecher, F. Khachik, C. S. Davis and G. Mulokozi (1995). Carotenoid content of thermally processed tomato-based food products. J. Ag. and Food Chem., 43,: 579-586.

Vergano, P. J. ; R. F. Testion; A. C. Choudhari and W. C. Newall (1992). Peach vibration bruising, The effect of paper and plastic films between peaches. J. of Food Quality 15 (3): 183-197.

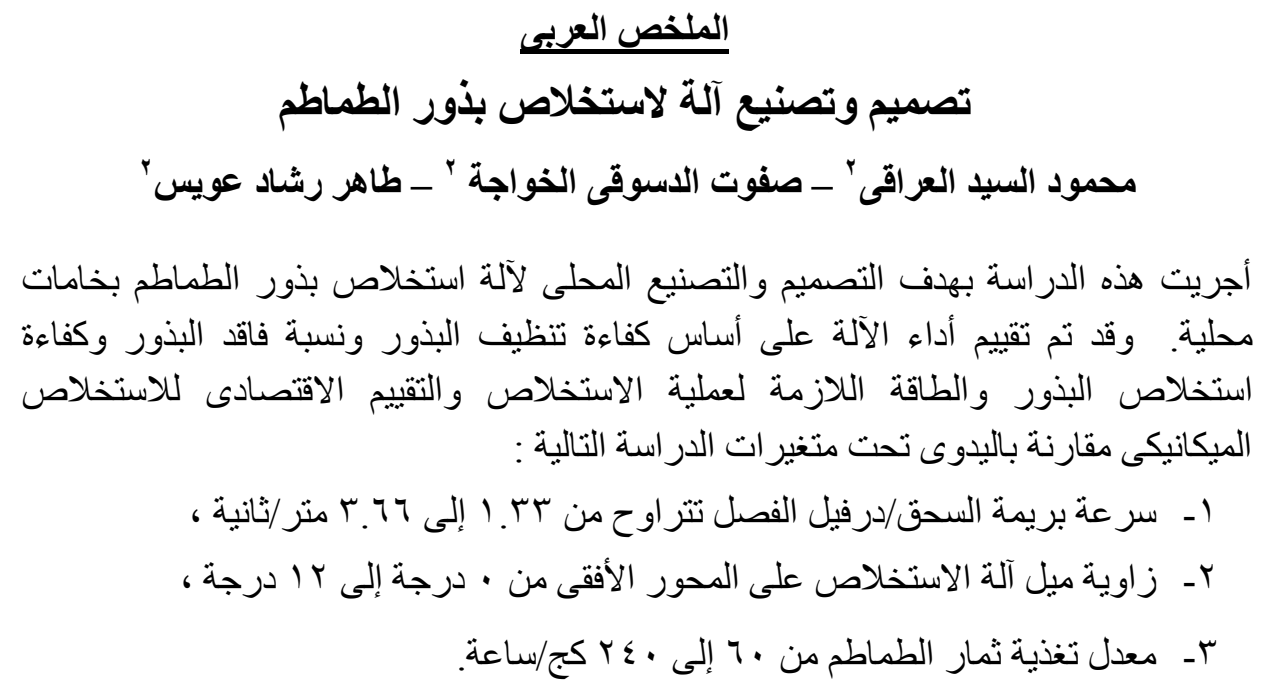




\section{وكاتت أهم النتائج المتحصل عليها كما يلح:-}

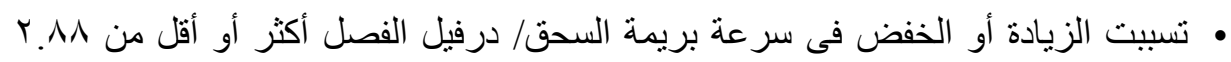

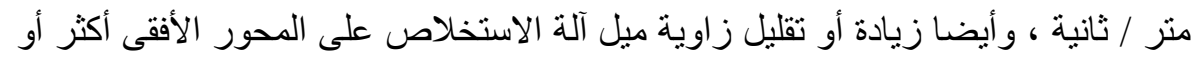

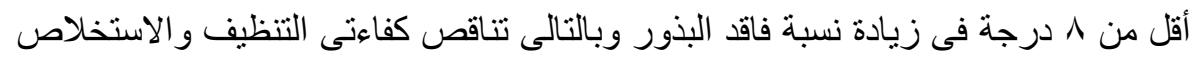

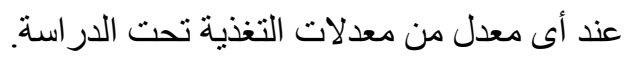

• وجد أن فاقد البذور يتناسب طرديا مع معدل التغذية. بينما كانت كفاءة تتظيف البذور

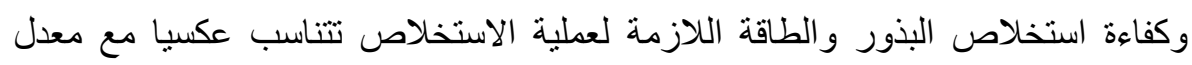
التغذية.

• أدى استخدام آلة الاستخلاص عند كل من سرعة بريمة السحق/ درفيل الفصل ^^ـــ متر/

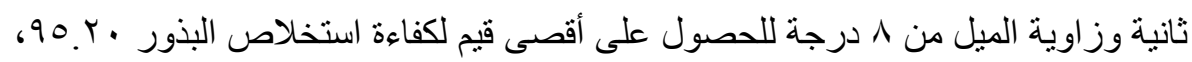

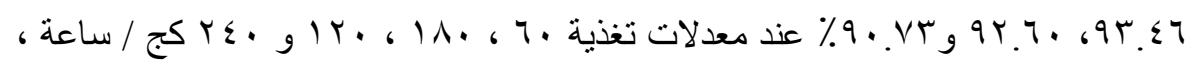
على التو الي.

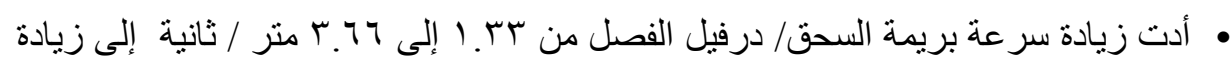

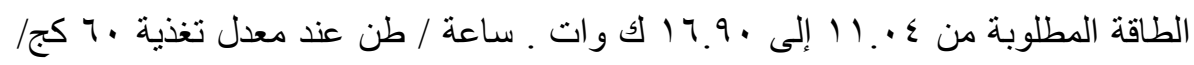

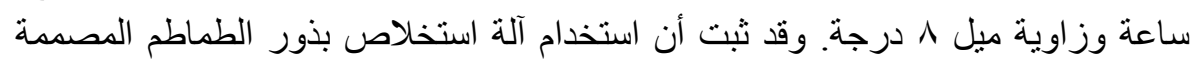

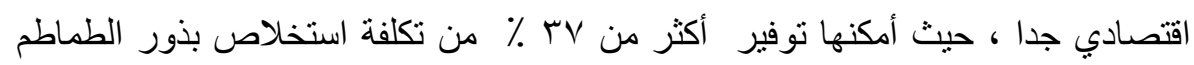
مقارنة بطريقة الاستخلاص اليدوية. 